\title{
MANIFESTASI HEROISME DALAM TRADISI JEPANG DAN JAWA Persamaan dan Perbedaan Dongeng Momotarō dan Epos Bharatayuda
}

\author{
Fajria Noviana \\ Fakultas Ilmu Budaya Universitas Diponegoro \\ Email : fajria_noviana@yahoo.com
}

\begin{abstract}
This comparative study was conducted to find out how heroism in Japanese and Javanese traditions is manifested into two literary works representing those traditions: Momotaro and Bharatayuda. This study is also aimed to find out the similarities of heroism manifestation in the two traditions. The reason for conducting this study is from the assumption that heroism is a universal concept. Therefore, such heroisms have similarities although they may come from different traditional backgrounds. Structural analysis and binary opposition were used in this study. The structural analysis was used to obtain the data on traditional background of the areas and the actions done by the main characters, while binary opposition was used to obtain the data on the main characters' heroic actions which were then concluded as the heroic manifestation. The result shows that the heroismmanifestation in Japanese and Javanese traditions has the following things in common: 1) conquering enemies, 2) protecting the members of the group, 3) keeping promise, 4) recompense, and 5) acting ethically. The result of this study can also prove the truth of the assumption.
\end{abstract}

Key words: heroism, heroic actions, Japanese and Javanese traditions

\section{PENDAHULUAN}

Heroisme adalah sebuah konsep moral yang universal. Menurut Bernstein (2002), terdapat empat komponen heroisme, yaitu: (a) bermoral besar; (b) berkemampuan; (c) berani bertindak di hadapan lawan; dan (d) mendapatkan kemenangan dalam taraf lahir atau batin. Sementara, landasan heroisme adalah komitmen terhadap moralitas yang tanpa kompromi.

Heroisme menjadi tema yang banyak terdapat dalam karya sastra, baik berupa sastra lisan maupun sastra bukan lisan. Dalam sastra lisan misalnya berwujud heroic drama yang menurut Abrams merupakan tiruan dari heroic poem atau lebih sering disebut sebagai epos (Abrams, 1999: 115-116). Istilah epos juga sering digunakan untuk menyebut prosa naratif yang menampilkan jiwa kepahlawanan dan menjangkau wilayah yang luas serta melibatkan kepentingan umat manusia (Abrams, 1999: 78).

Salah satu contoh prosa naratif yang demikian adalah dongeng Jepang berjudul Momotarō yang muncul pada zaman Muromachi (1333-1358). Dongeng ini berkisah tentang petualangan dan heroisme seorang pemuda bernama Momotarō bersama seekor anjing, seekor burung kiji, dan seekor monyet. Berempat mereka mengalahkan gerombolan oni yang sering mengganggu masyarakat desa tempat tinggal Momotarō. Oni adalah mahluk imajiner yang wujudnya menyerupai manusia bertubuh tinggi besar yang bertanduk dan bertaring.

Dongeng Momotarō berasal dari cerita rakyat yang disampaikan secara lisan. Dongeng ini terus hidup sampai sekarang karena kepopulerannya dalam masyarakat dan kisahnya dapat dinikmati oleh anakanak serta orang dewasa. Dongeng ini 
memiliki banyak versi, namun versi yang paling umum dijumpai sekarang merupakan versi yang mulai populer sejak akhir zaman Edo (1600-1868). Versi ini pula yang digunakan sebagai bacaan wajib bagi anakanak sekolah dasar di Jepang. Hal ini menjelaskan mengapa citra karakter Momotarō begitu meresap ke dalam berbagai karya seni dan karya sastra sejak zaman Muromachi sampai sekarang, hingga membuat dongeng ini menjadi cerita rakyat yang paling populer di Jepang dan menjadi ikon nasional Jepang (Polen, 2008: 3-4).

Epos terdapat di seluruh penjuru dunia dan tidak terhitung jumlahnya. Indonesia pun memiliki epos yang banyak dan beragam, salah satunya adalah Mahabharata. Mahabharata asli dari India sebenarnya merupakan syair berbahasa Sansekerta yang setelah masuk ke Jawa digubah oleh para pujangga Jawa Kuno ke dalam bentuk prosa, serta oleh para pujangga Jawa Baru ke dalam bentuk lakon dan macapat.

Mahabharata bercerita tentang asalusul nenek moyang Pandawa dan Kurawa sampai pecah perang antara kedua keluarga ini. Kisah peperangan ini, sejak penyebab terjadinya perang tersebut sampai beberapa saat setelah perang usai, disebut dengan Bharatayuda. Penggubahan lakon Bharatayuda sendiri mulai dikerjakan oleh Mpu Sedah dan diselesaikan oleh Mpu Panuluh pada masa pemerintahan Raja Jayabaya di Kediri (1135-1157).

Lakon Bharatayuda berkisah tentang perebutan tahta negeri Astina. Pandawa yang kalah dalam permainan judi dengan Kurawa karena kelicikan Sengkuni, harus menyerahkan Astina kepada Kurawa dan mengasingkan diri di hutan selama 12 tahun serta hidup dalam penyamaran selama 1 tahun. Setelah masa tersebut Pandawa seharusnya mendapatkan kembali Astina sesuai kesepakatan, tetapi karena Kurawa ingkar maka akhirnya perang besar pun terjadi untuk mengakhiri konflik panjang antara Pandawa dan Kurawa. Kisah peperangan ini diakhiri dengan kemenangan pihak Pandawa.
Melihat persamaan tema dan wujud tokoh dalam Momotarō dan Bharatayuda, maka kedua epos tersebut dibandingkan. Selain karena persamaan tema dan tokoh, keduanya pun telah menjadi bagian yang tidak terpisahkan dari masyarakat pendukungnya. Momotarō telah menjadi ikon nasional Jepang karena kepopulerannya, baik di dalam maupun di luar Jepang (Antoni, 1991: 163). Bharatayuda pun merupakan lakon wayang yang populer di Jawa dan tentu saja di India.

Selain popularitas, kedua cerita ini memiliki pengaruh yang cukup besar pada kebudayaan masing-masing. Dongeng Momotarō sampai saat ini tetap dikisahkan dalam masyarakat Jepang, baik dalam wujud cerita tertulis atau lisan maupun yang telah dialihwahanakan. Sementara, lakon Bharatayuda telah menjadi bagian dari pandangan dunia Jawa (Magnis-Suseno, 2001: 162).

Selain itu, kedua epos ini pun memiliki fungsi yang sama, yaitu untuk mengagungkan seseorang atau suatu kelompok tertentu. Momotarō diciptakan untuk mengagungkan kaum ksatria Jepang atau kaum samurai, sedangkan Bharatayuda digubah untuk mengagungkan keluhuran raja-raja Mataram sebagai keturunan dari Arjuna (Supomo, 2009: 943).

Dalam penelitian ini, permasalahan utama yang dibahas adalah bagaimana tema heroisme termanifestasikan ke dalam Momotarō dan Bharatayuda melalui para tokohnya dan apa sajakah persamaan manifestasi heroisme yang tercermin melalui tindakan para tokoh inti antara kedua teks yang berbeda latar tradisinya tersebut.

\section{LANDASAN TEORI}

Karena tindakan para tokoh inti Momotarō dan Bharatayuda dijadikan landasan deskripsi manifestasi heroisme, maka dalam penelitian ini digunakan analisis unsur intrinsik teks dan analisis dengan pendekatan strukturalisme naratologi Greimas, serta oposisi biner. 
Analisis unsur intrinsik teks digunakan untuk mendapatkan keterangan mengenai tokoh, penokohan, dan latar tradisi dari kedua teks. Analisis dengan pendekatan strukturalisme naratologi Greimas digunakan untuk mendapatkan keterangan mengenai tindakan-tindakan yang diambil oleh para tokoh inti dalam kedua teks. Sementara, oposisi biner digunakan untuk mendapatkan data yang selanjutnya dijadikan landasan deskripsi manifestasi heroisme dari masing-masing tradisi yang melatari kedua teks.

\section{Strukturalisme}

Unsur-unsur intrinsik yang dianalisis dalam penelitian ini dibatasi hanya pada tokoh, penokohan, dan latar tradisi.

Tokoh menurut Sudjiman (1988) adalah individu rekaan yang mengalami peristiwa atau berlakuan dalam berbagai peristiwa dalam cerita. Tokoh umumnya berwujud manusia, tetapi dapat juga berwujud binatang atau benda yang dimanusiakan. Tokoh menempati posisi yang strategis sebagai pembawa dan penyampai pesan, amanat, moral, atau sesuatu yang ingin disampaikan kepada pembaca, yang dapat diklasifikasikan ke dalam beberapa kelompok.

a. Tokoh Protagonis dan Tokoh Antagonis

Dalam karya sastra tradisional, pertentangan antara tokoh protagonis dan antagonis ditampilkan dengan sangat jelas. Tokoh protagonis mewakili pihak yang baik, sebaliknya tokoh antagonis mewakili pihak yang jahat (Sudjiman, 1988: 19).

Menilik penjelasan di atas, maka dalam Momotarō tokoh protagonisnya adalah Momotarō dan tokoh antagonisnya adalah gerombolan oni, sedangkan dalam Bharatayuda tokoh protagonisnya adalah Pandawa dan tokoh antagonisnya adalah Kurawa.

b. Tokoh Utama dan Tokoh Tambahan

Menurut Nurgiyantoro, tokoh yang tergolong penting ditampilkan terus-menerus sehingga terasa mendominasi sebagian besar cerita dan disebut sebagai tokoh utama.
Sebaliknya, tokoh yang dianggap kurang penting hanya dimunculkan sekali-kali dalam cerita dan itu pun mungkin dalam porsi penceritaan yang relatif singkat. Tokoh ini disebut sebagai tokoh tambahan (2002: 176).

Dari penjelasan di atas, maka dalam Momotarō tokoh utamanya adalah Momotarō, ketiga ekor binatang sekutunya, dan oni, sedangkan tokoh tambahannya adalah pasangan kakek dan nenek. Sementara, dalam Bharatayuda tokoh utamanya adalah Pandawa, Kurawa, Kresna, dan Bhisma, sedangkan tokoh tambahannya adalah para sekutu pihak Pandawa dan Kurawa.

c. Tokoh Datar dan Tokoh Bulat

Menurut Sudjiman (1988: 21), tokoh datar bersifat statis, wataknya sedikit sekali berubah, bahkan kadang sama sekali tidak berubah. Tokoh datar banyak digunakan dalam cerita didaktis yang umumnya tidak memerlukan perkembangan watak tokoh.

Sementara, tokoh bulat memiliki watak yang kompleks serta dimunculkan dengan detil sehingga sulit untuk dideskripsikan karena tokoh ini mirip dengan manusia di dunia nyata. Seperti halnya manusia di dunia nyata, tokoh ini ditampilkan dengan segala kekuatan dan kelemahannya (Abrams, 1999: 33 dan Sudjiman, 1988: 21).

Berdasarkan penjelasan di atas, maka dalam Momotarō tokoh datarnya adalah pasangan kakek dan nenek serta ketiga binatang sekutu Momotarō, sedangkan tokoh bulatnya adalah Momotarō dan panglima oni. Sementara, dalam Bharatayuda dapat dikatakan bahwa tidak ada tokoh datar karena semua tokoh utamanya adalah tokoh bulat.

Penokohan didefinisikan salah satunya sebagai penyajian watak tokoh (Sudjiman, 1988: 23). Penokohan dilakukan dengan dua metode, yaitu metode analitis dan dramatik.

a. Metode Analitis 
Dengan metode ini, tokoh dihadirkan disertai deskripsi diri yang dapat berupa sikap, watak, tingkah laku, atau bahkan ciri fisiknya (Nurgiyantoro, 2002: 195). Menurut Abrams (1999:34), melalui metode ini pengarang bahkan kadangkadang menilai motif dan watak sang tokoh.

Menilik penjelasan di atas, maka dapat dikatakan bahwa dalam Momotarō tidak terdapat penokohan secara analitis, sedangkan dalam Bharatayuda hampir semua penokohannya disajikan secara analitis.

b. Metode Dramatik

Dengan metode ini, watak tokoh dapat disimpulkan melalui pikiran, cakapan, dan lakuan tokoh yang disajikan pengarang, bahkan juga dari penampilan fisik dan gambaran lingkungan tokoh (Sudjiman, 1988: 26). Sementara menurut Abrams (1999: 33), dengan metode ini pengarang cukup menghadirkan sang tokoh bercakapcakap dan berlakuan, lalu membiarkan pembaca menyimpulkan sendiri motif dan watak sang tokoh yang tersirat dalam apa yang diucapkan dan apa yang dilakukannya.

Menilik penjelasan di atas, dapat dikatakan bahwa dalam Momotarō semua penokohannya disajikan secara dramatik, sedangkan dalam Bharatayuda hampir semua penokohannya disajikan secara analitis dan dramatik.

Latar memberikan pijakan cerita secara konkrit dan jelas untuk memberikan kesan realistis kepada pembaca. Hal ini dapat terjadi jika latar mampu mengangkat suasana dan warna lokal ke dalam cerita. Jika pembaca belum mengenal latar itu sebelumnya, maka pembaca justru akan memperoleh informasi baru yang bermanfaat.

Latar secara keseluruhan meliputi tempat, waktu, dan keadaan sosial tempat terjadinya berbagai peristiwa yang diceritakan (Abrams, 1999: 284).

a. Latar Tempat

Latar tempat dapat berupa nama daerah yang benar-benar ada, inisial tempat, ataupun penyebutan jenis dan sifat umum tempat tertentu. Penggunaan daerah yang nyata harus dideskripsikan setepat mungkin untuk menimbulkan kesan bahwa peristiwa dalam cerita itu benar-benar terjadi. Sementara, latar tempat yang tidak disebutkan secara jelas dapat disebabkan oleh perannya yang tidak terlalu penting dalam cerita.

Menilik penjelasan di atas, maka dapat dikatakan bahwa latar tempat dalam Momotarō adalah sebuah daerah antah berantah yang memiliki pulau Onigashima. Sementara, dalam Bharatayuda, hampir semua latar tempat masih menggunakan nama versi India yang di-Jawa-kan, namun pelukisannya mengesankan bahwa semua daerah yang muncul dalam cerita terdapat di pulau Jawa.

b. Latar Waktu

Latar waktu menunjukkan kapan terjadinya peristiwa dalam cerita. Dalam beberapa teks naratif, latar waktu hanya ditunjukkan misalnya dengan siang atau malam karena dalam kaitannya dengan logika cerita dianggap kurang penting.

Sesuai dengan penjelasan di atas, maka dapat dikatakan bahwa latar waktu dalam Momotarō adalah sejak Momotarō belum lahir sampai kembalinya ke desa setelah menang atas gerombolan oni. Sementara, latar waktu dalam Bharatayuda dimulai sejak Sentanu terpikat oleh Dewi Gangga sampai penobatan Parikesit sebagai raja Astina.

c. Latar Sosial

Latar sosial mengacu pada hal-hal yang berhubungan dengan perilaku kehidupan sosial suatu masyarakat di suatu tempat dan waktu seperti yang terdapat dalam cerita. Perilaku kehidupan sosial ini dapat berupa tradisi, religi, cara berpikir, dan lain-lain (Nurgiyantoro, 2002: 233). Selain itu, latar sosial dapat berupa penggunaan bahasa daerah atau dialek dan penamaan tokoh yang khas suatu daerah.

Latar sosial yang ditekankan dalam Momotarō dan Bharatayuda adalah pada 
latar tradisi masing-masing daerah asal, yaitu Jepang dan Jawa.

\section{Strukturalisme Naratologi}

Strukturalisme naratologi Greimas adalah analisis teks dengan cara membuat skema aktansial untuk mendeskripsikan naratif melalui berbagai elemen yang ada serta kombinasi elemen-elemen tersebut yang dapat ditemukan dalam cerita, baik fiksi maupun nonfiksi (Bertens, 1995: 69). Greimas mengembangkan model aktansial dengan menyajikan enam elemen dasar yang disebut aktan (Bertens, 1995: 69). Dalam teks naratif, aktan-aktan ini diwujudkan menjadi aktor. Aktan-aktan tersebut terbagi menjadi tiga pasang oposisi biner, yaitu subjek dan objek, penolong dan penentang, serta pengirim dan penerima. Apabila ketiga pasangan oposisi biner ini dihubungkan, maka akan membentuk skema aktansial. Bagi Greimas, keenam aktan dengan hubungan struktural yang tidak dapat diubah tersebut membangun dasar bagi semua naratif (Bertens, 1995: 70).

Dua aktan yang merupakan elemen dasar yaitu subjek dan objek. Subjek adalah yang memiliki keinginan untuk mendapatkan objek. Objek adalah sesuatu yang diinginkan oleh subjek melalui tindakan-tindakan yang diprakarsai oleh subjek. Keinginan subjek akan objek ini menyebabkan cerita menjadi berlanjut (Bertens, 1995: 69).

Dua aktan lain adalah penolong dan penentang. Penolong adalah yang mempermudah usaha subjek untuk mendapatkan objek. Penentang adalah yang menghalangi subjek untuk mendapatkan objek. Pasangan aktan terakhir yaitu pengirim dan penerima. Pengirim adalah yang mendorong untuk melakukan tindakan. Penerima adalah yang mendapatkan keuntungan.

\section{Oposisi Biner}

Sebagian besar teks yang berasal dari dunia imajinatif tersusun dari pasanganpasangan oposisi biner yang menyusun makna dari teks tersebut. Pasangan- pasangan oposisi biner ini dapat tampak dengan sangat jelas atau justru tersembunyi dalam teks. Oposisi biner yang tampak jelas biasanya akan menjadi penyebab munculnya oposisi biner yang tersembunyi dalam teks (Bertens, 1995: 128). Cakupan oposisi biner meliputi wilayah yang sangat luas dengan beberapa pasangan yang umum diketahui dan beberapa pasangan yang terikat pada budaya tertentu. Contoh pasangan yang umum diketahui adalah baik-buruk. Sementara, contoh pasangan yang terikat pada tradisi tertentu dapat dilihat dalam budaya Barat tentang kulit putih-kulit hitam. Satu dari pasangan ini selalu berfungsi sebagai pusat bagi yang lain karena keistimewaannya (Bertens, 1995: 129).

\section{PEMBAHASAN}

\section{Analisis Struktural Momotarō}

\section{a. Tokoh dan Penokohan}

Terdapat tujuh tokoh yang berperan dalam dongeng ini, yaitu Momotarō sebagai tokoh utama, sang kakek, sang nenek, anjing, burung kiji, monyet, dan panglima oni. Namun yang dibahas di sini hanya tokoh Momotarō. Metode penokohan yang digunakan dalam dongeng ini adalah metode dramatik.

Momotarō ditampilkan sebagai tokoh yang berani, baik hati, jujur, dan sopan. Kelahirannya sangat tidak lazim karena ia muncul dari dalam buah persik yang hanyut di sungai dan ditemukan oleh tokoh nenek yang sedang mencuci pakaian di sungai itu. Kelahirannya yang tidak lazim ini menunjukkan bahwa Momotarō bukanlah manusia biasa, tetapi merupakan (titisan) dewa. Sebagai seorang (titisan) dewa, Momotarō pasti memiliki berbagai kelebihan yang tidak dimiliki oleh manusia biasa. Dalam dongeng ini, kelebihannya diperlihatkan melalui cepatnya pertumbuhan tubuh dan akalnya, kemampuannya berbicara dengan binatang, dan kesaktiannya.

Keberanian Momotarō tampak dari usahanya untuk membebaskan desanya dari teror gerombolan oni. Ia pergi seorang diri ke tempat kediaman gerombolan itu, tanpa satu orang pun 
warga desa yang ikut bersamanya. Meskipun di tengah perjalanan ia bertemu dengan tiga ekor binatang yang akhirnya menjadi sekutunya, tetapi tetap saja kalah dari segi jumlah dibandingkan dengan gerombolan oni.

Setelah mengalahkan gerombolan tersebut, Momotarō menunjukkan kebaikan hatinya dengan mengampuni mereka. Panglima oni pun lalu memberikan gerobak penuh emas permata sebagai tanda terimakasih. Tanpa menguranginya, Momotarō membawa barang-barang tersebut pulang dan membagikannya kepada warga desa. Dari hal ini, jelas terlihat kejujuran Momotarō.

Kesopanan Momotarō tampak dari tindakannya memperkenalkan diri kepada gerombolan oni saat berhasil menerobos masuk ke tempat kediaman mereka, bukan langsung menyerbu. Memperkenalkan diri kepada orang lain, termasuk lawan, merupakan salah satu wujud reigi tadashii dalam masyarakat Jepang.

Selain hal-hal baik, Momotarō ternyata juga pernah melakukan hal yang kurang baik, yaitu meminta imbalan. Hal ini tampak jelas saat ia memberikan kue kibidango kepada tiga ekor binatang yang ditemuinya dalam perjalanan. Kibidango adalah sejenis makanan tradisional berbentuk bulat yang dibuat dari campuran mochigome dan kibi. Sejak dulu, kue mochi dan dango menjadi makanan sesaji bagi para dewa di Jepang. Kue ini dikatakan dapat meningkatkan kekuatan fisik siapa saja yang memakannya (Yamamoto, 2005: 117).

Momotarō meminta ketiga binatang itu menjadi anak buahnya dalam pertempuran melawan gerombolan oni jika mereka mau mendapatkan kibidango darinya. Sebagai seorang (titisan) dewa, ternyata Momotarō juga memiliki sisi manusiawi yang dapat dianggap sebagai kekurangan, yaitu meminta balas jasa.

\section{b. Latar Tradisi}

Latar tradisi yang dibahas meliputi latar tradisi tidak khas Jepang dan latar tradisi khas Jepang. Latar tradisi tidak khas Jepang yang pertama adalah kelahiran Momotarō yang tidak lazim, yaitu melalui media buah persik.

Kelahiran yang tidak lazim ini diikuti oleh ketidaklaziman lain. Saat baru muncul dari dalam buah persik, ukuran tubuh bayi Momotarō sangat kecil, tidak seperti bayi normal. Tetapi, setelah memakan dua mangkuk nasi, dengan sangat cepat Momotarō tumbuh menjadi seorang pemuda yang gagah.

Ketidaklaziman lain adalah kesaktian Momotarō, yang dalam konteks tradisi Jepang disamakan dengan kemampuan seorang samurai, tetapi dalam dongeng ini tidak disebutkan tentang latihan militer yang dijalaninya. Ini merupakan kemampuan tidak lazim yang menjadi latar tradisi tidak khas Jepang yang kedua.

Selain kemampuan bertempur, Momotarō juga memiliki kemampuan berbicara dengan binatang, yaitu anjing, burung kiji, dan monyet. Karena ketiga binatang tersebut tidak dikisahkan berbicara dengan manusia lain selain Momotarō, maka dapat dikatakan bahwa memang Momotarō memiliki kemampuan berbicara dengan binatang.

Latar tradisi khas Jepang dalam dongeng ini yaitu buah persik, kibidango, oni, konsep bushido, pakaian samurai, dan kedudukan anak laki-laki dalam keluarga Jepang.

Dalam tradisi Jepang, dipercaya bahwa para dewa memakan buah persik untuk menjaga keabadian mereka. Selain itu, buah persik juga dianggap dapat menyembuhkan penyakit dan menjaga supaya tetap awet muda (Polen, 2008: 13). Selain dalam hubungannya dengan kedewaan, buah persik juga merupakan simbol dari kesuburan, rahim, dan alat kelamin perempuan (Polen, 2008: 18). Oleh karena itu, pada bagian dongeng yang mengisahkan bayi Momotarō melompat ke luar dari buah persik yang 
akan dipotong sebenarnya merupakan simbolisasi dari proses persalinan seorang bayi.

Oni adalah mahluk imajiner yang wujudnya serupa dengan manusia, bertinggi badan sekitar dua meter, bertanduk satu atau dua, dan bertaring. Tempat tinggal oni umumnya di sebuah pulau kecil dan terpencil, di balik gunung, di tengah hutan belantara, atau di neraka (Yamamoto, 2005: 13-14). Mereka mengenakan pakaian yang terbuat dari kulit macan dan membawa gada besi. Dipercaya bahwa memajang patung monyet dapat menghalangi datangnya oni.

Bushidō adalah sebuah konsep budaya berisi aturan-aturan tidak tertulis yang dipegang teguh oleh kaum bushi atau ksatria, atau lebih dikenal dengan sebutan kaum samurai. Mereka sebenarnya berasal dari kaum petani yang direkrut dan dilatih secara khusus melalui wajib militer untuk menjadi seorang samurai (Turnbull, 2003: 13). Bushidō menekankan pada kesetiaan dan pengabdian diri secara total kepada atasan dan orangtua, suatu konsep yang menjadi landasan moral masyarakat Jepang (Bellah, 1992: 121). Selain itu, bushidō juga mengajarkan keadilan, keberanian, kebaikan hati, kesopanan, kejujuran, kehormatan, dan pengendalian diri (Nitobe, 2004).

Dalam ilustrasinya, Momotarō mengenakan pakaian khas kaum samurai sejak keberangkatannya untuk menaklukkan gerombolan oni. Selain Momotarō, tidak ada tokoh lain yang mengenakan pakaian ini. Hal ini menunjukkan bahwa Momotarō adalah satu-satunya samurai dalam dongeng ini. Masyarakat Jepang menganggap anak laki-laki adalah anggota keluarga paling utama. Anak laki-laki adalah perwujudan dari kemapanan sosial, kepastian akan masa depan, dan penerus nama keluarga (Polen, 2008: 11). Oleh karena itu, orang Jepang akan dapat langsung memahami betapa pasangan kakek dan nenek dalam dongeng ini berada dalam situasi yang sulit tanpa kehadiran seorang anak laki-laki (Polen, 2008: 11). Sementara, kehadiran Momotarō sendiri dapat dipastikan adalah berkat kemurahan hati para dewa, karena bagaimanapun juga adalah tidak mungkin bagi pasangan kakek dan nenek ini untuk memiliki anak kandung di usia senja.

c. Analisis Dengan Strukturalisme Naratologi Greimas

Langkah pertama adalah membuat skema aktansial untuk mengetahui fungsi dan relasi tiap aktan. Langkah berikutnya adalah membuat struktur hubungan fungsional untuk mengetahui peran subjek dalam melaksanakan tugas dari pengirim. Berikut ini adalah penjelasan dari bagan skema aktansial utama dongeng Momotarō, sedangkan bagannya dapat dilihat di bagian Lampiran.

Korelasi antar aktan dimulai dari objek dan subjek Subjek Momotarō akhirnya mendapatkan objek, yaitu kebahagiaan dan ketenteraman bagi diri dan lingkungannya.

Korelasi berikutnya pada pengirim dan penerima. Pengirimnya berwujud penderitaan kakek dan nenek yang tidak memiliki anak serta warga desa yang diteror oleh gerombolan oni. Penerimanya adalah mereka semua yang pada akhirnya berhasil mendapatkan apa yang mereka inginkan.

Penolong dan penentang dalam dongeng ini sama-sama berwujud bukan manusia. Penolongnya adalah tiga ekor binatang yang membantu Momotarō dalam pertempuran, sedangkan penentangnya adalah gerombolan oni.

\section{Analisis Struktural Bharatayuda}

\section{a. Tokoh dan Penokohan}

Karena tokoh dalam epos ini sangat banyak, maka yang dianalisis dibatasi hanya pada tokoh-tokoh yang paling banyak muncul dan/atau yang kemunculannya memberi pengaruh cukup signifikan dalam perkembangan cerita. Tokoh yang berasal dari pihak 
Pandawa yaitu Dewi Kunti, Yudhistira, Bima, Arjuna, dan Kresna. Tokoh yang berasal dari pihak Kurawa adalah Duryudana, Dursasana, Durna, Karna, dan Bhisma. Metode penokohan yang digunakan adalah gabungan antara metode analitis dan metode dramatik. Berikut ini adalah analisis penokohan mereka.

Kunti ditampilkan sebagai seorang istri dan ibu teladan yang setia mendampingi dan selalu berusaha menyenangkan hati suaminya. Kunti memiliki mantra pemanggil dewa supaya dikaruniai anak yang digunakannya karena Pandu tidak mungkin memberinya anak, padahal suaminya sangat ingin memiliki keturunan. Mantra ini diajarkannya kepada Dewi Madrim madunya, agar dapat juga memiliki anak. Hal ini menunjukkan usaha Kunti untuk menyenangkan hati Pandu.

Sebagai seorang ibu, ia tidak hanya membesarkan dan mendidik anak kandungnya, namun juga anak dari Madrim yang menerjunkan diri ke dalam api pembakaran jenazah Pandu. Kunti selalu mendampingi kelima anaknya dalam susah dan senang sejak masih kanak-kanak hingga mereka memberinya cucu.

Kunti pernah berbuat ceroboh dengan merapal mantra pemanggil dewa sebagai coba-coba saat ia belum menikah. Akibatnya, lahirlah Karna dari telinga kirinya yang kemudian dilarungnya di sungai sehingga kehormatan Kunti yang hamil di luar nikah tetap terjaga.

Yudhistira sang sulung Pandawa ini ditampilkan sebagai sosok yang bijaksana, mampu mengontrol emosi secara sempurna, sebisa mungkin menjauhi perselisihan, berbudi luhur, sangat sabar dan tidak pernah berdusta sehingga darahnya berwarna putih. Meskipun demikian, Yudhistira pun memiliki kekurangan, salah satunya adalah senang berjudi. Hal ini terbukti dari diterimanya ajakan Kurawa untuk bermain judi dadu dengan taruhan tidak hanya harta benda dan negeri Amarta, namun juga kemerdekaan diri Yudhistira, para Pandawa, dan bahkan Drupadi istrinya.

Kemampuan Yudhistira mengontrol emosi atau tidak bereaksi apapun saat Drupadi dipermalukan Dursasana di depan umum sebagai akibat kekalahannya bermain judi, sebenarnya justru merupakan suatu hal yang negatif. Bagaimanapun juga, seseorang seharusnya melindungi diri dan keluarganya dari segala hal buruk yang datang menimpa; kapanpun, di mana pun, dan dengan cara apapun.

Yudhistira pernah menyamarkan kebenaran, bukan berdusta, untuk kepentingan diri pribadi dan kelompoknya. Ini dilakukannya kepada Durna yang sangat membantu Kurawa saat perang Bharatayuda berlangsung untuk mematahkan semangatnya.

Bima, anak kedua Pandawa, ditampilkan sebagai tokoh yang bertubuh tinggi besar dan memiliki kekuatan yang luar biasa. Bima yang selalu menjadi pelindung ibu dan keempat saudaranya adalah sosok yang jujur, lurus, tidak pernah merasa ragu-ragu, dan tidak pernah menyerah. Oleh karena itu, ia menjadi kekuatan utama Pandawa yang selalu dapat diandalkan. Meskipun demikian, ia pun memiliki beberapa kelemahan, yaitu cara bicaranya yang jauh dari halus, senang berkelahi, dan berkesan 'haus darah'.

Arjuna, anak ketiga Pandawa, juga selalu diandalkan untuk menghalau serangan musuh. Ia dijuluki sebagai lelananging jagad karena keindahan raga dan tindak-tanduk serta tutur katanya sehingga dapat dikatakan tidak ada perempuan yang tidak menginginkannya. Sayangnya, karena sadar akan ketampanan dan kesaktiannya, ia selalu berusaha mendapatkan perempuan untuk dijadikan istri, meskipun jumlah istrinya sudah sangat banyak, tanpa mempedulikan kondisi istrinya yang lain. Hal ini merupakan tindakan yang tidak bertanggung jawab dari ksatria lelananging jagad. 
Kresna ditampilkan sebagai orang yang bijaksana dan selalu menjadi pelindung bagi yang lemah. Kresna adalah pribadi yang sangat jarang marah, tetapi jika ia dibuat murka, maka ia akan bertriwikrama dan berubah menjadi raksasa sebesar bukit dengan seribu tangan dan seribu kaki. Dalam perang Bharatayuda, Kresna sebenarnya tidak diperbolehkan oleh Batara Guru untuk membela pihak yang manapun. Namun, demi terlaksananya takdir kemenangan Pandawa atas Kurawa, maka Kresna melakukan tindakan melanggar etika bertempur.

Duryudana sejak bayi sepertinya memang sudah ditakdirkan untuk menjadi tokoh hitam, karena bersamaan dengan saat ia dilahirkan terdengar suara lolongan anjing hutan yang dianggap sebagai pertanda buruk (Bharatayuda, 48). Duryudana adalah tokoh yang menghalalkan segala cara untuk mendapatkan apa yang ia inginkan. Meskipun digambarkan sebagai tokoh yang segala tindakannya negatif, tetapi Duryudana pun memiliki beberapa sifat positif, yaitu berkemauan kuat, berpikiran jauh ke depan, dan berjuang sampai akhir hayat.

Dursasana, adik Duryudana, mempunyai peran yang cukup penting, terbukti dari kemunculannya dalam tiap episode yang melibatkan Kurawa dengan Pandawa. Tokoh ini selalu bertingkah semaunya. Tanpa mengabaikan segala sifat dan perilaku buruknya, Dursasana sebenarnya seorang adik yang sangat setia kepada Duryudana. Ia selalu mendukung penuh segala keputusan dan tindakan sang kakak.

Durna adalah guru bagi Pandawa dan Kurawa. Durna sebenarnya orang baik dan sangat menyayangi Pandawa, terutama Arjuna. Namun, karena merasa berhutang budi kepada Astina yang diperintah oleh Duryudana, maka dalam perang Bharatayuda ia terpaksa membela pihak Kurawa.

Karna sebenarnya kakak seibu dengan Pandawa. Ayahnya adalah Batara Surya yang secara tak sengaja 'dipanggil' oleh Kunti saat mencoba keampuhan mantra pemanggil dewa yang dimilikinya hingga Kunti dikaruniai anak. Karna berhutang budi kepada Duryudana yang telah mengangkat derajatnya sehingga ia merasa wajib membalasnya dengan memihak Kurawa dalam perang Bharatayuda, meskipun ia sadar bahwa pada akhirnya Kurawa akan kalah. Bahkan, meskipun sebelum perang Kunti dan Kresna sudah berusaha membujuk Karna agar berpihak kepada Pandawa yang notabene adalah saudara kandungnya, ia menolaknya yang menunjukkan sifat setia Karna yang tidak tergoyahkan.

Bhisma adalah anak hasil pernikahan Prabu Sentanu dari Astina dengan Dewi Gangga. Karena merupakan keturunan dewa, Bhisma diceritakan sangat sakti. Bhisma pun sangat berbakti kepada orangtua dan negara. Oleh karena itu, apapun dilakukannya demi menunjukkan baktinya tersebut, meskipun kadangkadang kelak membawa akibat yang tidak baik. Tanda bakti Bhisma kepada orangtua ditunjukkan dengan kerelaannya menyerahkan tahta Astina yang menjadi haknya kepada saudarasaudara tirinya dari Dewi Durgandini, istri baru ayahnya setelah Dewi Gangga kembali ke kahyangan, yang kelak menjadi nenek Pandawa dan Kurawa. Ia pun bersumpah untuk tidak menikah selamanya agar tidak memiliki anak yang kelak mungkin akan menuntut hak atas tahta Astina.

\section{b. Latar Tradisi}

Latar tradisi yang dibahas di sini meliputi latar tradisi tidak khas Jawa dan latar tradisi khas Jawa. Latar tradisi tidak khas Jawa yang pertama adalah kelahiran yang tidak lazim, yaitu kelahiran Karna melalui telinga kiri Kunti. Ketidaklaziman lain adalah kesaktian Karna. Meskipun ia diasuh oleh orang dari golongan rakyat jelata yang berprofesi sebagai kusir dan tidak pernah mendapatkan latihan olah 
kanuragan, tetapi ia sangat hebat dalam bidang memanah hingga Duryudana mengangkatnya menjadi seorang panglima perang. Ia bahkan nyaris mengalahkan Arjuna dalam perang Bharatayuda.

Berikutnya adalah cairan penambah kesaktian. Cairan berupa minyak yang dilumurkan ke tubuh Duryudana ini membuat ia kebal senjata, kecuali paha kirinya karena tidak terlumuri.

Latar tradisi berikutnya adalah budaya patriarkis. Ini membuat pewaris tahta kerajaan haruslah anak laki-laki pertama. Jika tidak ada atau anak tersebut dianggap tidak mampu, maka pewarisnya adalah anak laki-laki kedua, dan seterusnya. Budaya patriarkis lain yang tampak dalam adalah adanya anggapan bahwa kaum perempuan hanya objek bagi kaum laki-laki. Sebagai objek, perempuan diwajibkan untuk mematuhi apa yang sudah ditentukan oleh laki-laki. Sebagai contoh adalah adanya sayembara adu kesaktian bagi kaum laki-laki untuk memperebutkan putri raja yang diadakan oleh sang raja sendiri, seperti yang tejadi pada Kunti. Contoh lain adalah usaha Dursasana untuk mempermalukan Drupadi yang dijadikan 'barang taruhan' oleh Yudhistira suaminya yang kalah berjudi. Saat itu Drupadi hanya bisa menahan malu dan amarah, demi baktinya pada suami.

Berikutnya adalah kesan negatif bagian tubuh sebelah kiri. Dalam etika Timur, anggota tubuh sebelah kanan digunakan untuk hal-hal yang bersifat baik dan bersih, dan sebaliknya dengan anggota tubuh sebelah kiri. Oleh karena itu, kesan negatif kehamilan Kunti di luar nikah ditunjukkan dengan proses persalinannya yang melalui telinga kiri. Sementara, kelemahan fisik Duryudana 'diletakkan' pada paha kirinya yang tidak terkena minyak.

Setelah latar tradisi tidak khas Jawa di atas, berikut ini adalah latar tradisi khas Jawa yang meliputi buta dan pandangan dunia Jawa.
Buta diberi nama sesuai wujud lahiriahnya. Mereka tidak memiliki wilayah tempat tinggal dan silsilah hidup yang jelas. Mereka bahkan dapat muncul di episode mana pun meskipun sebelumnya telah dibunuh. Figur buta ini ditampilkan sebagai mahluk dari seberang yang buas dan kasar. Karena berasal dari seberang, otomatis buta bukanlah manusia Jawa. Ditampilkannya sosok buta merupakan sebuah upaya pengontrasan untuk menunjukkan kenggulan dan 'kehalusan' orang Jawa (Suseno, 2001: 166-167).

Latar berikutnya adalah pandangan dunia Jawa. Pertama adalah konsep manunggaling kawula-Gusti yang tercermin dari menitisnya Dewa Wisnu ke dalam diri Kresna dan Bima yang masuk ke dalam tubuh Dewaruci. Kedua adalah konsep sangkan paraning dumadi. Pengetahuan tentang hal ini baru dapat diperoleh setelah menjalani laku prihatin dan bahkan mempertaruhkan nyawa. Ini seperti yang dilakukan Bima yang melakukan perjalanan untuk mencari air suci (Susetya, 2008: 214). Ketiga adalah konsep sedulur papat lima pancer yang merupakan simbol 'empat saudara gaib' manusia, yaitu ketuban, tembuni, darah, dan plasenta, sedangkan pancer atau pusatnya adalah diri manusia itu sendiri sehingga total berjumlah lima. Konsep ini diwujudkan dalam hubungan antara Pandawa dengan Kresna. Meskipun Pandawa berjumlah lima, tetapi karena Nakula dan Sadewa adalah saudara kembar, maka mereka dianggap satu sehingga Pandawa menjadi sedulur papat dengan Kresna sebagai pancer karena Kresna-lah yang menjadi penasehat dan pembimbing Pandawa.

\section{c. Analisis Dengan Strukturalisme Naratologi Greimas}

Berikut ini adalah penjelasan dari bagan skema aktansial utama, sedangkan bagannya dapat dilihat di bagian Lampiran. 
Korelasi antar aktan dimulai dari objek dan subjek. Subjek Pandawa dan Kurawa sama-sama memiliki nafsu untuk berkuasa sebagai pengirimnya. Astina merupakan objek bagi kedua subjek yang pada akhirnya didapatkan oleh pihak Pandawa sebagai penerima.

Perebutan Astina melalui perang Bharatayuda sebagai penolong, dilakukan setelah berbagai upaya diplomasi menemui kegagalan. Perang ini sebenarnya sudah ditakdirkan oleh para dewa sebagai penentang bagi subjek Kurawa, karena bagaimanapun juga keangkaramurkaan harus lenyap dari muka bumi. Oleh karena itu, para dewa pun sudah mengetahui bahwa pada akhirnya Pandawa-lah yang akan menjadi pemenang dalam perang besar tersebut.

\section{Integrasi Skema Aktansial Momotarō dengan Bharatayuda}

Kedua teks naratif yang diteliti ternyata dapat dideskripsikan secara singkat melalui sebuah skema aktansial yang dapat dilihat pada bagian Lampiran.

Tokoh protagonis dalam kedua teks yang diteliti, yaitu Momotarō dan Pandawa, menjadi subjek dalam skema aktansial ini. Mereka sama-sama menginginkan kedamaian yang baru dapat terwujud dalam kondisi tertentu. Kondisi tersebut dalam Momotarō berarti tiadanya teror dari gerombolan oni, sedangkan dalam Bharatayuda berarti tiadanya keangkaramurkaan Kurawa. Keduanya diperoleh dengan cara yang sama, yaitu melalui kemenangan dalam pertempuran.

Keinginan para subjek untuk mendapatkan kedamaian dilandasi oleh penderitaan yang dialami. Dalam Momotarō, penderitaan ini dialami oleh warga desa, sedangkan dalam Bharatayuda penderitaan ini dialami oleh Pandawa. Penderitaan-penderitaan ini pada dasarnya disebabkan oleh hal yang sama, yaitu keserakahan.

Gerombolan oni dan para Kurawa yang bersifat serakah dalam skema aktansial ini menjadi penyebab timbulnya penderitaan yang merupakan pengirim. Mereka juga sekaligus menjadi penentang bagi subjek sesuai dengan kedudukan mereka sebagai tokoh antagonis. Sementara, penolong bagi subjek adalah sekutu masing-masing tokoh protagonis.

Pertempuran para tokoh protagonis melawan para tokoh antagonis akhirnya dimenangkan oleh para tokoh protagonis. Dengan kemenangan ini, maka kedamaian bagi kolektif penerima pun berhasil diciptakan. Kedamaian dalam Momotarō dirasakan oleh warga desa, sementara dalam Bharatayuda dirasakan terutama oleh para Pandawa.

\section{Manifestasi Heroisme}

Analisis pada subbab ini mencakup oposisi biner tentang baik-buruk dan tindakan pengecut-heroik dari masingmasing teks serta persamaan manifestasi heroisme antara tradisi Jepang dan Jawa. Oposisi biner di sini disajikan dalam bentuk paragraf.

\section{a. Baik-Buruk}

Hal baik dari dongeng Momotarō adalah Momotarō sendiri dan sekutunya, kakek dan nenek, buah persik, dan kue kibidango. Sedangkan hal buruknya adalah panglima oni dan gerombolannya serta Momotarō sendiri.

Momotarō dan sekutunya telah melindungi keluarga dan warga desa tempat tinggal Momotarō dari ancaman panglima oni serta gerombolannya. Kakek dan nenek mengizinkan Momotarō pergi untuk menaklukkan gerombolan oni, meskipun dapat berakibat buruk bagi Momotarō, anak satu-satunya yang mereka dapatkan saat memasuki usia senja. Ini menunjukkan bahwa kakek dan nenek mendahulukan kepentingan umum daripada kepentingan pribadi. Sementara, buah persik menjadi perantara lahirnya Momotarō ke dunia dan membawa kebahagiaan dalam kehidupan pasangan kakek dan nenek yang menjadi orangtua angkat Momotarō. Terakhir adalah kue kibidango yang menjadi bekal makanan 
Momotarō dalam petualangannya menuju pulau Onigashima untuk menaklukkan gerombolan oni. Kue ini dipercaya dapat meningkatkan kekuatan fisik siapa saja yang memakannya.

Hal buruk pertama yang dibahas yaitu panglima oni dan gerombolannya. Mereka adalah mahluk serakah yang menghalalkan segala cara untuk mendapatkan apa yang mereka inginkan. Sementara, sisi negatif Momotarō adalah meminta imbalan atas apa yang telah diberikannya, meskipun hal ini tidak selalu ia lakukan. Selain meminta imbalan, ternyata Momotarō pun mau menerima suap jika hal tersebut dianggapnya menguntungkan, yaitu harta dari panglima oni dengan imbalan kebebasan mereka.

Dalam Bharatayuda, yang termasuk hal baik adalah semua pihak Pandawa, Duryudana, Karna, dan Bhisma. Sementara, hal buruknya adalah semua pihak Kurawa dan Yudhistira.

Tidak dapat dipungkiri, Pandawa dan orang-orang yang berpihak pada mereka selalu dimunculkan sebagai tokoh protagonis yang berhasil menumpas keangkaramurkaan. Mereka pun memiliki berbagai keunggulan, baik lahiriah maupun batiniah. Oleh karena itulah, otomatis semua pihak Pandawa masuk ke dalam kategori segala hal yang bersifat baik.

Duryudana dimasukkan ke dalam kategori ini berdasarkan tiga sifat positif yang dimilikinya. Pertama adalah berkemauan kuat yang dapat dilihat dari segala usahanya untuk mendapatkan tahta Astina. Kedua adalah pikiran Duryudana yang jauh ke depan yang dapat dilihat dari kesadarannya akan harus adanya orang-orang yang setia dan dapat diandalkan jika ia ingin menguasai Astina. Ketiga adalah perjuangannya yang sampai akhir hayat tampak di hari terakhir perang Bharatayuda, saat yang tersisa dari pihak Kurawa hanyalah dirinya sendiri dan sedikit prajurit, ia tetap maju menghadapi Bima.
Karna yang merasa berhutang budi kepada Duryudana membuat ia merasa wajib memihak Kurawa dalam perang Bharatayuda. Selain itu, kesediaan Karna untuk mengakui Kunti sebagai ibu kandung dan menuruti sebagian permintaannya juga merupakan sesuatu yang baik, mengingat Kunti tidak pernah memberi kasih sayang kepada Karna bahkan melarungnya di sungai begitu ia dilahirkan. Bhisma, seperti halnya Pandawa, juga tidak dapat dipungkiri merupakan tokoh baik. Baktinya yang sangat besar kepada orangtua dan negara merupakan buktinya. Nasionalisme Bhisma terlihat saat ia membela Astina, tempat ia dilahirkan dan dibesarkan, dalam perang Bharatayuda.

Hal buruk yang pertama dibahas adalah semua pihak Kurawa, karena dapat dikatakan bahwa mereka sumber keangkaramurkaan di dunia wayang (Bharatayuda, 64). Kedua adalah Yudhistira. Ia memanfaatkan reputasinya sebagai manusia yang tidak pernah berdusta untuk menyamarkan kebenaran dari Durna untuk kepentingan pihak Pandawa. Kemudian, kepasifannya dengan hanya duduk diam saat Drupadi istrinya dipermalukan Dursasana di depan matanya dan banyak orang lain.

\section{b. Tindakan Heroik-Pengecut}

Tindakan heroik yang tampak dari dongeng Momotarō yang pertama adalah berbagi sesuatu yang jumlahnya terbatas, yaitu kue kibidango. Berikutnya adalah tindakan Momotarō menaklukkan dan mengampuni musuh, melindungi anggota kelompok, menepati janji, membalas jasa, dan bertindak sesuai etika yang berlaku, yaitu dengan memperkenalkan diri kepada gerombolan oni.

Sementara, tindakan pengecut yang tampak dari Momotarō adalah meminta imbalan jasa dan menyerang musuh saat mereka tidak siap, sedangkan dari gerombolan oni adalah memberikan harta sebagai imbalan (suap) untuk 
memuluskan urusan dan merampas milik orang yang lebih lemah.

Tindakan heroik yang tampak dalam Bharatayuda adalah melindungi anggota kelompok, mematuhi aturan yang telah disepakati bersama, menegakkan hukum, menepati janji, membalas jasa, membela negara, menaklukkan musuh, dan berjuang sampai akhir hayat.

Sementara, tindakan pengecut yang tampak adalah berlaku curang, mempertaruhkan sesuatu yang seharusnya tidak dipertaruhkan dalam permainan judi, merampas milik orang lain, membunuh musuh secara sembunyi-sembunyi, bertindak di luar etika yang berlaku, mengingkari janji, memikirkan kepentingan pribadi dan anggota kelompoknya saja tanpa mempedulikan yang lain, tidak bertanggung jawab, menghalalkan segala cara untuk mendapatkan yang diinginkan, dan berkhianat.

\section{c. Persamaan Manifestasi Heroisme dalam Tradisi Jepang dan Jawa}

Setelah mengetahui bagaimana heroisme termanifestasikan dalam tradisi Jepang dan Jawa yang disimpulkan melalui berbagai tindakan heroik dalam Momotarō dan Bharatayuda, maka persamaan manifestasi heroisme dalam kedua tradisi yang berbeda tersebut yaitu: (1) menaklukkan musuh; (2) melindungi anggota kelompok; menepati janji; (4) membalas jasa; dan (5) bertindak sesuai dengan etika yang berlaku

Dari analisis di atas, dapat dilihat bahwa tokoh-tokoh dalam Momotarō hampir semuanya ditampilkan secara baik-buruk. Dalam Momotarō, hanya tokoh Momotarō yang ditampilkan dengan sangat sedikit sikap kurang baik, sedangkan tokoh-tokoh dalam Bharatayuda ditampilkan sekaligus dengan sikap baik dan buruknya sehingga terkesan lebih manusiawi. Selain itu, dalam Bharatayuda terdapat banyak tokoh yang tindakannya berkesan ambigu. Meskipun demikian, tokoh protagonis atau yang ditampilkan dengan lebih banyak sikap baik dari kedua cerita sama-sama berupaya untuk menyelamatkan dan melestarikan kehidupan di dunia.

\section{SIMPULAN}

Karena fokus penelitian ini adalah pada manifestasi heroisme, maka persamaan yang dilihat adalah pada manifestasi heroisme itu sendiri dalam tradisi Jepang dan Jawa berdasarkan pada apa yang ditemukan dalam dongeng Momotarō dan epos Bharatayuda. Lima persamaan manifestasi heroisme tersebut adalah seperti yang tertulis pada bagian akhir Pembahasan.

Dongeng Momotarō yang ditujukan untuk anak-anak memiliki tokoh-tokoh datar dan penokohan yang hampir seratus persen hitam-putih, sama seperti cara anak-anak yang masih polos dalam memandang dunia. Sementara, epos Bharatayuda dengan tokoh-tokoh bulatnya membuat epos ini berkesan lebih hidup dan nyata. 


\section{DAFTAR PUSTAKA}

Abrams, M.H. 1999. A Glossary of Literary Terms. Massachusetts: Heinle \& Heinle.

Antoni, Klaus. 1991. "Momotaro (The Peach Boy) and the Spirit of Japan: Concerning the Function of a Fairy Tale in Japanese Nationalism of the Early Showa Age". Artikel dalam Asian Folklore Studies, Volume 50, 1991: 155-188. Diunduh dari http: //www. nanzan-u.ac.jp/SHUBUNKEN publications/afs/ pdf/a835.pdf pada tanggal 10 Februari 2010.

Bellah, Robert N. 1992. Religi Tokugawa, Akar-akar Budaya Jepang. (Alih bahasa oleh Wardah Hafidz dan Wiladi Budiharga). Jakarta: Gramedia Pustaka Utama.

Bertens, Hans. 1995. Literary Theory: The Basics. London: Routledge.

Magnis-Suseno, Franz. 2001. Etika Jawa. Jakarta: PT Gramedia Pustaka Utama.

Nitobe, Inazo. 2004. Bushido, The Soul of Japan. Project Gutenberg EBook\#12096. Diunduh dari http://www.scribd.com/doc/84 21853/BushidoSoul-of-Japan
Inazo-Nitobe pada tanggal 6 Juli 2009.

Nurgiyantoro, Burhan. 2002. Teori Pengkajian Fiksi. Yogyakarta: Gadjah Mada University Press.

Polen, James Scott. 2008. "Continuity and Change of Momotarō". Tesis pada Faculty of Arts and Sciences, University of Pittsburgh. Tidak dipublikasikan.

Ratna, Nyoman Kutha. 2008. Teori, Metode, dan Teknik Penelitian Sastra. Yogyakarta: Pustaka Pelajar.

Sudjiman, Panuti. 1988. Memahami Cerita Rekaan. Jakarta: Pustaka Jaya.

Supomo. $2009 . \quad$ "Men-Jawa-kan Mahabharata". Artikel dalam Sadur: Sejarah Terjemahan di Indonesia dan Malaysia. Jakarta: Kepustakaan Populer Gramedia.

Susetya, Wawan. 2008. Bharatayuda. Yogyakarta: Kreasi Wacana.

Turnbull, Stephen. 2003. Samurai, The World of The Warrior. Oxford: Osprey Publishing Ltd.

Yamamoto, Kōzō (ed). 2005. Nihon no Mukashibanashi. Tokyo: Gakushū Kenkyūsha. 


\section{Bagan 1. Skema Aktansial Utama Dongeng Momotarō}

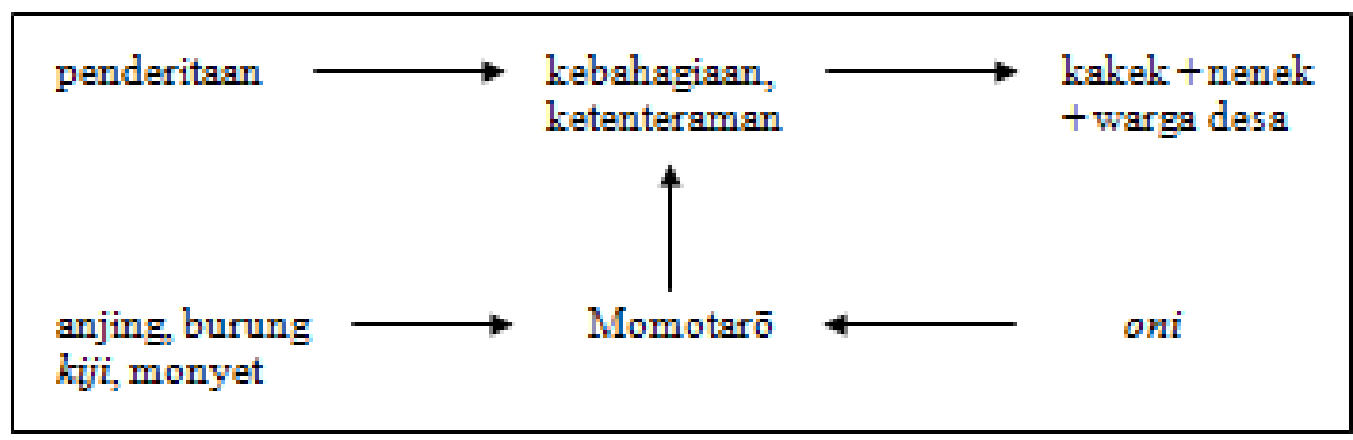

Bagan 2. Skema Aktansial Utama Epos Bharatayuda

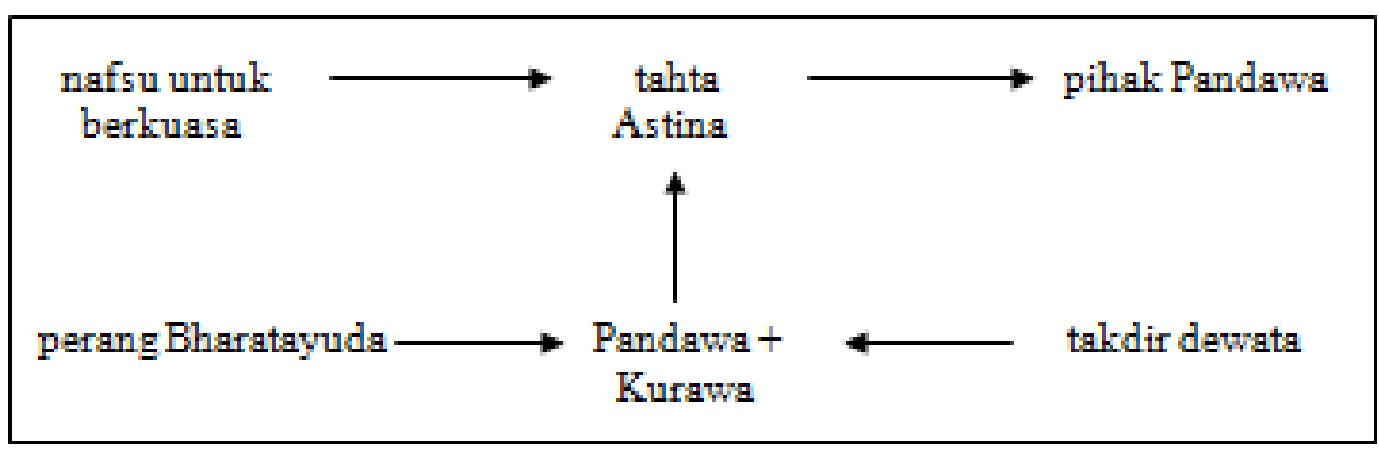

Bagan 3. Integrasi Skema Aktansial Momotarō dan Bharatayuda

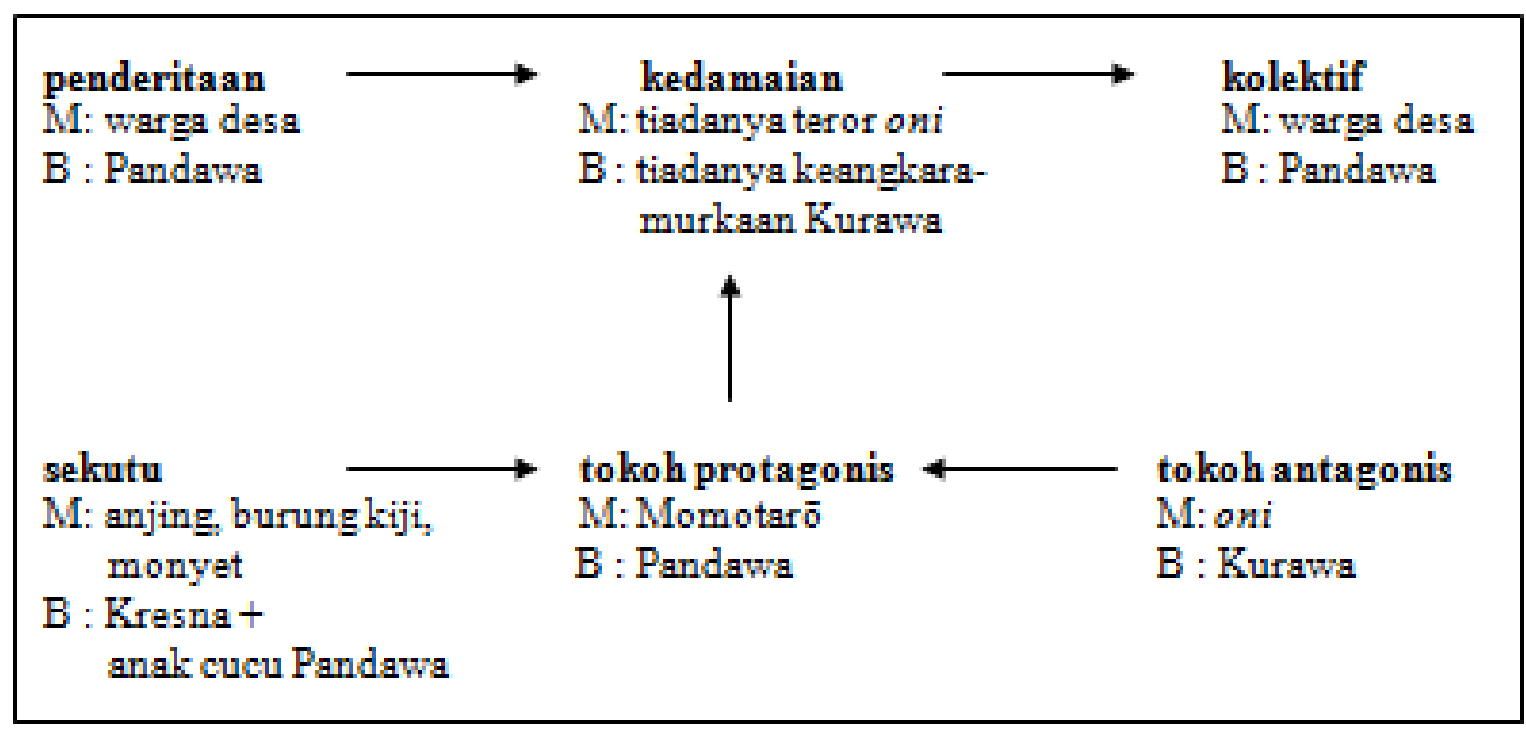

